\title{
The Research on Export Trade of Agricultural Products in Jilin Province
}

\author{
Lihong Zhao \\ Jilin engineering normal university, Jilin Changchun,130031,China \\ 32387515@qq.com
}

\author{
Keywords: Jilin Province; Agriculture; Products; Export; Trade
}

\begin{abstract}
The paper starts with the status quo of export trade of agricultural products in Jilin Province, and analyzes the main problems in the export of agricultural products in Jilin Province. Aiming at the major problems existing in the export of agricultural products in Jilin Province, corresponding countermeasures and suggestions are proposed.
\end{abstract}

\section{Introduction}

Jilin province is located in the central part of Northeast China. Jilin Province is an important commodity grain production base in China, with advantageous conditions for agricultural production. It is one of the main grain producing areas and the "six major forest areas" and "the eight grasslands". The area of the province's jurisdiction is 187,400 square kilometers, of which $5,378,800$ acres are arable land, accounting for $28.98 \%$ of the total area, and 0.21 hectares of cultivated land per capita are 2.18 times the national average level. The total population is $27,523,800$, of which the rural population is $12,438,000$, accounting for $45.19 \%$.Jilin province belongs to the temperate continental monsoon climate, the four seasons are clear, the rain and heat are in the same season, the annual average precipitation in the west is about 400 millimeters, the middle is 600 millimeters, and the East is more than 800 millimeters. The frost free period of the year is 135 days.

\section{The Present Situation of Agricultural Products Export Trade in Jilin}

The export trade of agricultural products in Jilin Province from 2006 to 2013 showed an upward trend in total agricultural product exports. The total export volume from 423.39 million U.S. dollars in 2006 increased to 63.760 million U.S. dollars in 2013, and its annual growth rate was $6.78 \%$. However, the rate of increase is still lower than the average level of national agricultural exports, which is only about one third of the national average growth rate. Jilin Province is a major agricultural province. Each year, agricultural products not only meet the needs of the province and the country, but a considerable portion of them are exported to foreign countries and enter the international market. Since the beginning of the 21st century, Jilin Province's agricultural exports have occupied a large proportion of foreign trade in Jilin Province. Agricultural products are also major foreign trade products. The gross export volume of agricultural products accounts for one third of the whole Jilin Province's total exports. Exports of agricultural products are also very important from a national perspective and have remained in the top ten in the country for a long period of time. In particular, since the accession of China to the WTO, the reduction of the market access threshold of agricultural products, the reduction of restrictions, the development of the market, and the favorable external conditions have also contributed to the continuous increase in the total foreign trade volume of agricultural products in Jilin Province. Jilin province is a traditional agricultural province, mainly growing corn, soybean and its processed products. With the economic development, the people's income level has been continuously improved. The people's demand for food is not only to "full stomach" but also to "high quality foods" and to pay special attention to the health of eating. Therefore, Jilin Province develops green and organic foods and continuously increases its output, so that the proportion of agricultural products that make up the output also increases. At the same time, Jilin Province has also developed agricultural products with 
various characteristics of Jilin Province, such as ginseng, edible fungus and wild vegetables, and increased its production inputs. Table 1 shows the export statistics of major agricultural products in Jilin Province in 2014. As shown in Table 1.

Table 1 shows the export statistics of major agricultural products in Jilin Province in 2014

\begin{tabular}{lll}
\hline Product Name & Number[ton] & $\begin{array}{c}\text { Amount [ten thousand } \\
\text { dollars] }\end{array}$ \\
\hline Meat and its chop & 5708 & 2031 \\
Aquatic products & 26667 & 8054 \\
medicinal materials & 4783 & 9850 \\
Vegetables & 28787 & 8977 \\
Fresh, dried fruit and nuts & 10308 & 14412 \\
foodstuff & 180000 & 16571 \\
Edible oil seed & 40435 & 4654 \\
Total export & & 577771 \\
\hline
\end{tabular}

Data source: Monthly Report on China's Agricultural Import and Export

\section{The Main Problems in Export Trade of Agricultural Products in Jilin Province}

The agricultural products export trade of Jilin province showed an upward trend from 2006 to 2013, However, according to the 2016 customs statistics[1], the total agricultural product export of Jilin province declined 3\% from the previous year's statistics. Among them, the total output of pigs, cattle, sheep, and poultry meat in Jilin Province was 2.5555 million tons in 2016, a decrease of $0.1 \%$ from the previous year. Thereinto, pork production was 1.3056 million tons, a decrease of $4.0 \%$; beef output was 471,000 tons, an increase of $1.1 \%$; mutton production was 48,100 tons, an increase of $0.6 \%$; the output of poultry meat was 730,800 tons, an increase of $6.9 \%$. The output of poultry eggs was $1,144,400$ tons, an increase of $6.7 \%$. Raw milk production was 528,500 tons, an increase of $1.0 \%$.At the end of the year, the number of live pigs on hand was 9.4807 million, a decrease of 2.5\%; the total number of live pigs slaughtered was 16,193,400, a decrease of $2.7 \%$.

Unreasonable Export Structure of Agricultural Products. In the export trade of agricultural products in Jilin Province, the proportion of primary products and bulk products is too high. For example, in the statistics table 2, In 2015, exports of aquatic products accounted for $2.3 \%$ of total exports in Jilin Province. Exports of fresh and dry fruits and nuts accounted for 4.4 per cent of total exports, while food exports accounted for 2.6 per cent. For example, tin the statistics table 2.However, the proportion of exports with high technological content is relatively small. The export structure of agricultural products in Jilin Province is irrational and affects the improvement of the export efficiency of agricultural products. 
Table 2 Customs statistics on total exports of major agricultural products in Jilin in 2015

\begin{tabular}{lll}
\hline Product Name & Number[ton] & $\begin{array}{c}\text { Amount ([ten thousand } \\
\text { dollars] }\end{array}$ \\
\hline Meat and its chop & 3418 & 1130 \\
Aquatic products & 39794 & 10883 \\
medicinal materials & 2778 & 5558 \\
Vegetables & 21628 & 4856 \\
Fresh, dried fruit and & 14034 & 20570 \\
nuts & 120000 & 12261 \\
foodstuff & 40093 & 4458 \\
Edible oil seed & & 465382 \\
Total export & &
\end{tabular}

Data source: Monthly reports on China's import and export of agricultural products

Single Export Market Structure of Agricultural Products. Statistics show that Jilin mainly exports to Japan, South Korea, Germany, the United States, Russia and ASEAN countries[2], as shown in Table 3. Because of the excessive concentration of the export market, it is easy to suffer from the domestic economic fluctuations of the importing countries and the impact of protectionist measures on agricultural products trade[3,4]. The risk of the international market of agricultural products is relatively concentrated. Once the import policies of agricultural products in these countries change, it will inevitably affect the overall export share of agricultural products in Jilin province[5].

Table 3 Table of imports and exports to major countries (regions) in Jilin province (2015): $\$ 10000$

\begin{tabular}{llll}
\hline State (region) & $\begin{array}{l}\text { Gross import and } \\
\text { export value }\end{array}$ & Total export & Total import \\
\hline Japan & 168829 & 42350 & 126479 \\
The Republic of Korea & 68253 & 44940 & 23313 \\
Germany & 676315 & 26402 & 649913 \\
$\begin{array}{l}\text { Russia } \\
\text { The United States of }\end{array}$ & 52090 & 26999 & 25090 \\
$\begin{array}{l}\text { America } \\
\text { ASEAN(the Association }\end{array}$ & 97130 & 45180 & 51951 \\
of Southeast Asian & 91633 & & \\
Nations & 1154250 & 62622 & 29011 \\
Gross value & & 248493 & 905757 \\
\hline
\end{tabular}

\section{Main Countermeasures and Suggestions for Agricultural Products Export Trade in Jilin Province}

Improving the Export Structure of Single Agricultural Products. Jilin should improve the export structure of single agricultural products according to the changes of market demand[6]. Based on the export pattern that traditional industries, key industries and emerging industries promote each other and coordinate development, based on the unique natural advantages of Jilin Province, develop the trade of specialty agricultural products and develop the international market for specialty agricultural products. For example, ginseng, pilose antler, Acanthopanax, and related medicines such as gentian and gentian are not only of good quality, but also have the highest output in the country[7,8].

Enlarging the Export Market Structure of Agricultural Products. On the basis of maintaining the original export market structure of agricultural products, Jilin province pays more attention to the development of emerging markets, striving to improve the ability to open up the 
market, so that the export growth of agricultural products in Jilin can keep up with the pace of world market and improve the trade environment of agricultural products[9]. We should adhere to the enterprise as the main body, give full play to the advantages of existing resources and products, implement the strategy of consolidating and expanding the traditional market and actively developing emerging markets, and diversifying the development of the international market for agricultural products, and gradually form an international market system for agricultural products with complementary advantages and suitable for the development of Jilin's export-oriented agriculture. That is to say, Jilin needs to adjust the geographical structure of agricultural exports, optimize the market structure and cultivate diversified export markets.

Pay Attention to the Management of the Quality and Safety of Agricultural Products.In the quality management of agricultural products export, Jilin should produce and process according to the international standards to improve the quality and safety level of agricultural products. First of all, we should strengthen the education, training and publicity of the quality and safety of agricultural products. In accordance with the principles of focusing on key points, easy to be difficult, from point to face, and gradually pushing forward, the agricultural operation norms should be promoted, and a team of enterprises and technicians who are trained and trained to control the safety and quality of the export of agricultural products should be trained and encouraged to speed up the agricultural products. Quality standard certification will enhance the international competitiveness of agricultural products in Jilin province. Secondly, we should accelerate the construction of the quality standard system of agricultural products, actively promote the ISO9000 quality management system, ISO14000 environmental management system and HACCP food quality safety guarantee system certification, and form a model of environmental protection and safety management of agricultural products that are in line with the international standards[10].

\section{Reference}

[1] 2016 Jilin Satistical Yearbook , Beijing: China Statistics Publishing House, 2016

[2] Ministry of Commerce of People's Republic of Chinahttp://www.mofcom.gov.cn/

[3] T.Feng. Research on international competitiveness of agricultural products in Jilin , management and Technology (2014,04:) 177-178.

[4] M.Huang.Research on China's agricultural products import management,Southwestern University of Finance and Economics, 2012.

[5] People's Republic of China National Bureau of Statisticshttp://www.stats.gov.cn/

[6] Z.X.Lv, Countermeasures to enhance the international competitiveness of Jilin's main agricultural products,Journal of Jilin ECONOMIC MANAGEMENT CADRE COLLEGE, 2012,01:41-43.

[7] Monthly Report on China's Import and Export of AgriculturalProducts2015.12

[8] Monthly Report on China'sImport and Export of Agricultural Products2014.12

[9] J.Li. Study on the export of agricultural products in Jilin Province, shopping malls modernization, 2013, (17): 43-44.

[10] Y.Wang and H.J.Zhao. Analysis of the current situation and Countermeasures of agricultural products export in Jilin province,Bohai economic outlook, 2018,02:73 - 74 